Original Research Paper

\title{
Efektifitas LKPD Elektronik sebagai Media Pembelajaran pada Masa Pandemi Covid-19 untuk Guru di YPI Bidayatul Hidayah Ampenan
}

\author{
Miqro' Fajari Lathifah ${ }^{1 *}$, Baiq Nunung Hidayati ${ }^{1}$, Zulandri $^{1}$ \\ ${ }^{1}$ Program Studi Magister Pendidikan IPA, Universitas Mataram, Mataram, Indonesia
}

https://doi.org/10.29303/jpmpi.v3i2.668

Sitasi: Lathifah, M. F., Hidayati, B. N., \& Zulandri. (2021). Efektifitas LKPD Elektronik sebagai Media Pembelajaran pada Masa Pandemi Covid-19 untuk Guru di YPI Bidayatul Hidayah Ampenan. Jurnal Pengabdian Magister Pendidikan IPA, 4(1)

\section{Article history}

Received: 03 Februari 2021

Revised: 08 Maret 2021

Accepted: 06 April 2021

*Corresponding Author:

Miqro' Fajari Lathifah,

Universitas Mataram, Mataram, Indonesia.

Email:

fajarilathifah@gmail.com

\begin{abstract}
Abstrak: Pandemi Covid-19 memeberikan dampak yang cukup besar pada berbagai aspek kehidupan manusia. Salah satunya yaitu pada bidang pendidikan. Akibat dari wabah tersebut, kegiatan belajar mengajar yang seharusnya dilaksanakan secara tatap muka, terpaksa harus dilaksanakan secara daring (online). Menyikapi hal tersebut, pengembangan media pembelajaran khususnya yang memanfaatkan teknologi sangatlah diperlukan. Tujuan dilakukannya pengabdian ini adalah untuk membantu guru di YPI Bidayatul Hidayah dalam mengembangkan LKPD elektronik yang dapat digunakan sebagai alternative pembelajaran di masa pandemic Covid-19. LKPD elektronik dibuat menggunakan aplikasi Liveworksheet. Program pengabdian kepada masyarakat (PKM) ini dilaksanakan dalam dua tahap, yaitu: tahap persiapan dan pelaksanaan. Hasil kegiatan pengabdian masyarakat terlihat bahwa peserta pelatihan sangat antusias terhadap pelaksanaan kegiatan karena mendapatkan pengetahuan baru terkait pengembangan LKPD elektronik.
\end{abstract}

Kata kunci: Covid-19, LKPD Elektronik, Liveworksheet, Media Pembelajaran.

\section{Pendahuluan}

Pandemi Covid-19 berdampak pada dunia pendidikan, termasuk pendidikan menengah pertama. Virus corona merupakan wabah yang menghambat kegiatan belajar mengajar yang biasanya berlangsung secara tatap muka. Namun demikian, dengan adanya pandemi ini mampu mengakselerasi pendidikan 4.0. Revolusi Industri 4.0 merupakan keadaan industri abad ke-21 saat perubahan besar-besaran di berbagai bidang lewat perpaduan teknologi yang mengurangi sekat-sekat antara dunia fisik, digital, dan biologi. Sistem pembelajaran dilakukan jarak jauh dengan memanfaatkan teknologi informasi. Pelaksanaan model pembelajaran jarak jauh memiliki tantangan besar. Salah satunya, banyak guru belum terbiasa menggunakan sistem pembelajaran yang bersifat blended dan sepenuhnya online (Ramadhani, 2020).

Mendikbud (2020) menegaskan dalam surat edaran No. 4 Tahun 2020 tentang pelaksanaan kebijakan pendidikan dalam masa darurat penyebaran corona virus desease (covid-19) memutuskan bahwa pembelajaran di Indonesia dilaksanakan secara daring yang artinya menggunakan akses internet. Setiap jenjang sekolah pada akhirnya memaksakan diri menggunakan media daring atau dalam jaringan untuk dapat melaksanakan pembelajaran. Pelaksanaaan pembelajaran daring ditentukan oleh beberapa faktor pendukung diantaranya handphone, kuota dan jaringan internet serta ketersediaan bahan ajar yang sesuai (Putria et al., 2020). 
Media adalah alat bantu apa saja yang dapat dijadikan sebagai penyalur pesan guna mencapai tujuan pengajaran (Djamarah, 2002). Muson (2010) mengemukanan bahwa, media merupakan wadah dari pesan yang oleh sumber atau penyalurnya ingin diteruskan kepada sasaran atau penerima pesan tersebut. Oleh karena itu, guna meningkatkan efektivitas dan efisiensi pembelajaran, perlu dikembangkan berbagai model pembelajaran yang kreatif dan inovatif. Hal ini perlu dilakukan agar proses pembelajaran tidak terkesan kurang menarik, monoton dan membosankan sehingga akan menghambat terjadinya transfer of knowledge. Oleh karena itu peran media dalam proses pembelajaran menjadi penting karena akan menjadikan proses pembelajaran tersebut menjadi lebih bervariasi dan tidak membosankan. Selain itu, penggunaan media juga bertujuan untuk menyampaikan pesan pembelajaran, sehingga mencapai tujuan yang ingin diperoleh dari proses belajar yang telah dilakukan.

Media pembelajaran yang sering digunakan di sekolah adalah Lembar kerja Peseta didik (LKPD). Depdiknas (2004) mengartikan LKPD sebagai lembaran-lembaran berisi tugas yang harus dikerjakan oleh peserta didik, biasanya berupa petunjuk atau langkah-langkah untuk menyelesaikan suatu tugas dan tugas tersebut haruslah jelas kompetensi dasar yang akan dicapai. Kemudian Arief (2015) menyatakan bahwa "LKPD merupakan salah satu sarana untuk membantu dan mempermudah dalam kegiatan pembelajaran sehingga akan terbentuk interaksi yang efektif antara peserta didik dengan guru, dan dapat meningkatkan aktifitas peserta didik dalam peningkatan prestasi belajar". LKPD biasanya memuat judul LKPD, kompetensi dasar, waktu penyelesaian, bahan/peralatan yang digunakan, informasi singkat, langkah kerja, tugas yang harus dilakukan, dan laporan yang harus dikerjakan. Sehingga LKPD masih sangat dibutuhkan untuk menunjang pembelajaran yang lebih efektif untuk beberapa pelajaran yang membutuhkan pemahaman melalui latihan-latihan soal seperti pada pelajaran IPA.

LKPD yang ada dalam bentuk cetak masih belum efektif dan kurang praktis digunakan dalam penggunaannya. Sehingga menurut Herawati et al (2016) Untuk mengoptimalkannya baik dari segi tampilan maupun kualitas pembelajaran dibutuhkan transformasi yang berbasis konvergensi teknologi informasi dan telekomunikasi (TIK). Dalam transformasi itu LKPD cetak bisa digantikan fungsinya dengan LKPD interaktif agar materi pelajaran bisa lebih hidup, lebih mendalam serta dapat meningkatkan daya inovasi dan menambah kreativitas siswa. LKPD yang interaktif merupakan salah satu alternative yang dapat digunakan untuk menunjang proses pembelajaran yang terdiri dari materi dan latihan soal-soal yang dapat diakses melalui perangkat elektronik seperti computer atau HP.

Menurut Dewi (2010) bahwa Pembelajaran yang dilakukan dengan LKS interaktif dapat membuat suasana belajar yang menyenangkan dan tidak membosankan, siswa tidak akan merasa tertekan, tidak takut untuk bertanya dan suasana pembelajaran tidak akan membuat siswa tegang. Kemudian Prastowo (2015) mengemukakan bahwa LKPD memiliki 4 fungsi sebagai berikut:1) Sebagai bahan ajar yang meminimalkanperan pendidik, namunlebih mengaktifkan peserta didik. 2) Sebagai bahan ajar yang mempermudah untuk memahami materi yang diberikan. 3) Sebagai bahan ajar yang ringkas dan kaya tugas untuk berlatih. 4) Memudahkan pelaksanaan pengajaran kepada peserta didik. LKPD ini nantinya dapat diakses oleh peserta didik melalui jaringan internet dengan harapan dapat membantu peserta didik untuk lebih memahami materi yang diberikan oleh guru sehingga tujuan pembelajaran dapat tercapai.

Salah satu bentuk LKPD interaktif yaitu peggunaan LKPD elektronik, dimana LKPD elektronik merupakan lembaran latihan peserta didik yang dikerjakan secara digital dan dilakukan secara sistematis serta berkesinambungan selama jangka waktu tertentu (Ramlawati et al., 2014). LKPD elektronik ini dapat dirancang dan dikreasikan sesuai dengan tujuan yang ingin dicapai dalam proses pembelajaran serta kreativitas masing-masing guru, dimana nantinya peserta didik dapat mengakses LKPD elektronik ini melalui jaringan internet dengan harapan dapat membantu peserta didik untuk lebih memahami materi yang diberikan oleh guru sehingga tujuan pembelajaran dapat tercapai.

Berdasarkan uraian di atas, maka perlu diacakan kegiatan untuk mengedukasi dan memberi pemahaman kepada guru di sekolah mengenai manfaat LKPD eletronik serta langkah-langkah pengemgambangan LKP elektronik sebagai media 
yg membantu efektivitas pembelajaran pada masa pandemic Covid-19.

\section{Metode}

Kegiatan pengabdian kepada masyarakat ini dilaksanakan pada hari Sabtu, 27 Februai 2021 yang bertempat di Yayasan Pendidikan Islam (YPI) Bidayatul Hidayah Ampenan, Mataram. Adapun mitra yang terlibat dalam kegiatan ini adalah guruguru SMP di YPI Bidayatul Hidayah yang diberikan pelatihan mengenai cara membuat LKPD elektronik sebagai media pembelajaran alternative pada masa pandemic covid-19.

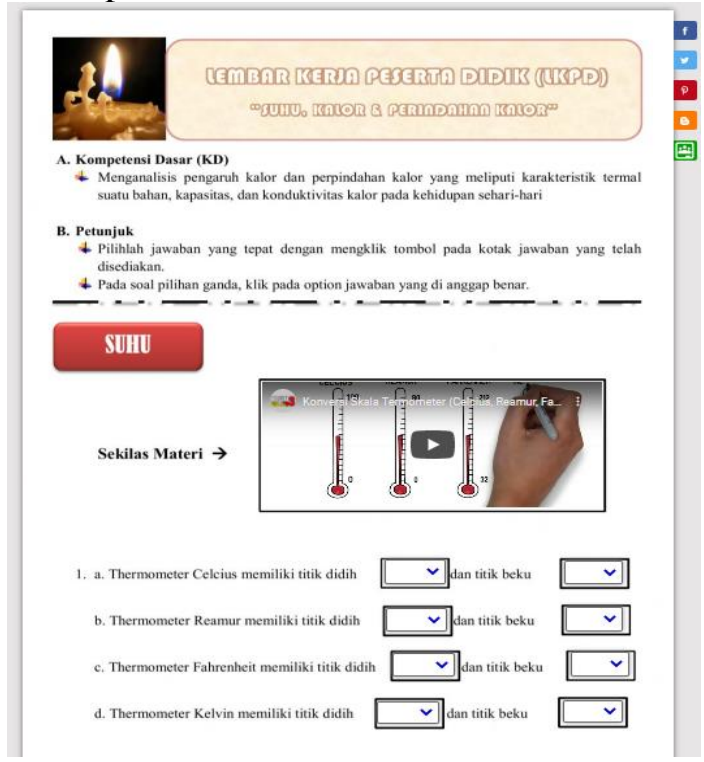

Gambar 1. Tampilan Halaman Pertama LKPD

\section{b. Tahap Pelaksanaan}

Pada Tahap pelaksanaan, kegiatan pengabdian yang dilakukan adalah sosialisasi dan pelatihan. Pertama, panitia pelaksana (tim pengabdian Pascasarjana UNRAM) menyampaikan materi mengenai efektivitas LKPD elektronik
Program pengabdian kepada masyarakat $(\mathrm{PKM})$ ini dilaksanakan dalam dua tahap, yaitu:

\section{a. Tahap Persiapan}

Langkah awal dalam melaksanakan kegiatan pengabdian ini adalah melakukan persiapan, mulai dari menyusun materi, mengurus izin hingga melakukan konsolidasi dengan pihak mitra yang akan menjadi sasaran kegiatan.

Sebelum disampaikan kepada sasaran kegiatan, terlebih dahulu dibuat contoh LKPD elektronik. Adapaun gambaran LKPD elektronik yang telah dibuat adalah sebagai berikut:

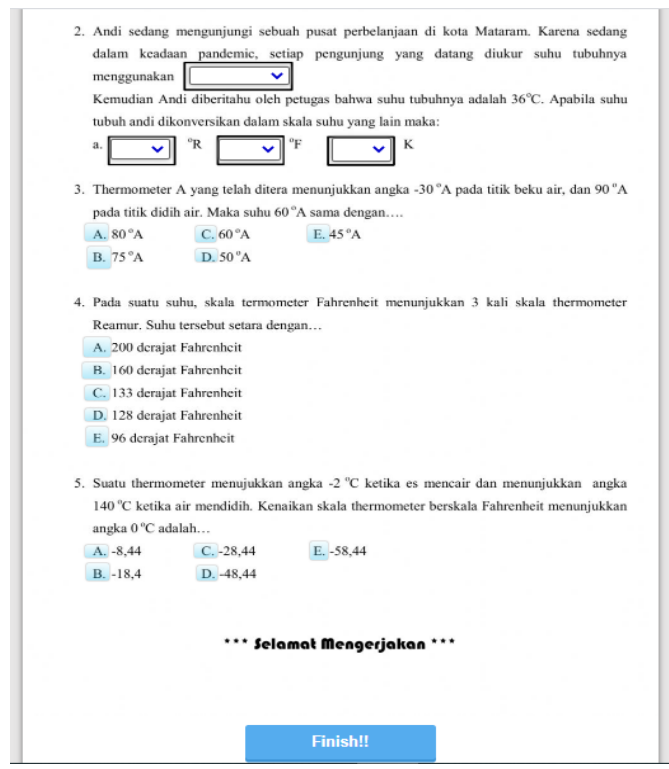

Gambar 2. Tampilan Halaman Kedua LKPD

sebagai media pembelajaran pada masa pandemic Covid-19 serta menjelaskan secara singkat langkahlangkah pembuatan LKPD Elekktronik. Kedua, guru-guru sebagai mitra (sasaran) kegiatan melakukan latihan pembuatan LKPD elektronik yang dibimbing oleh panitia. 


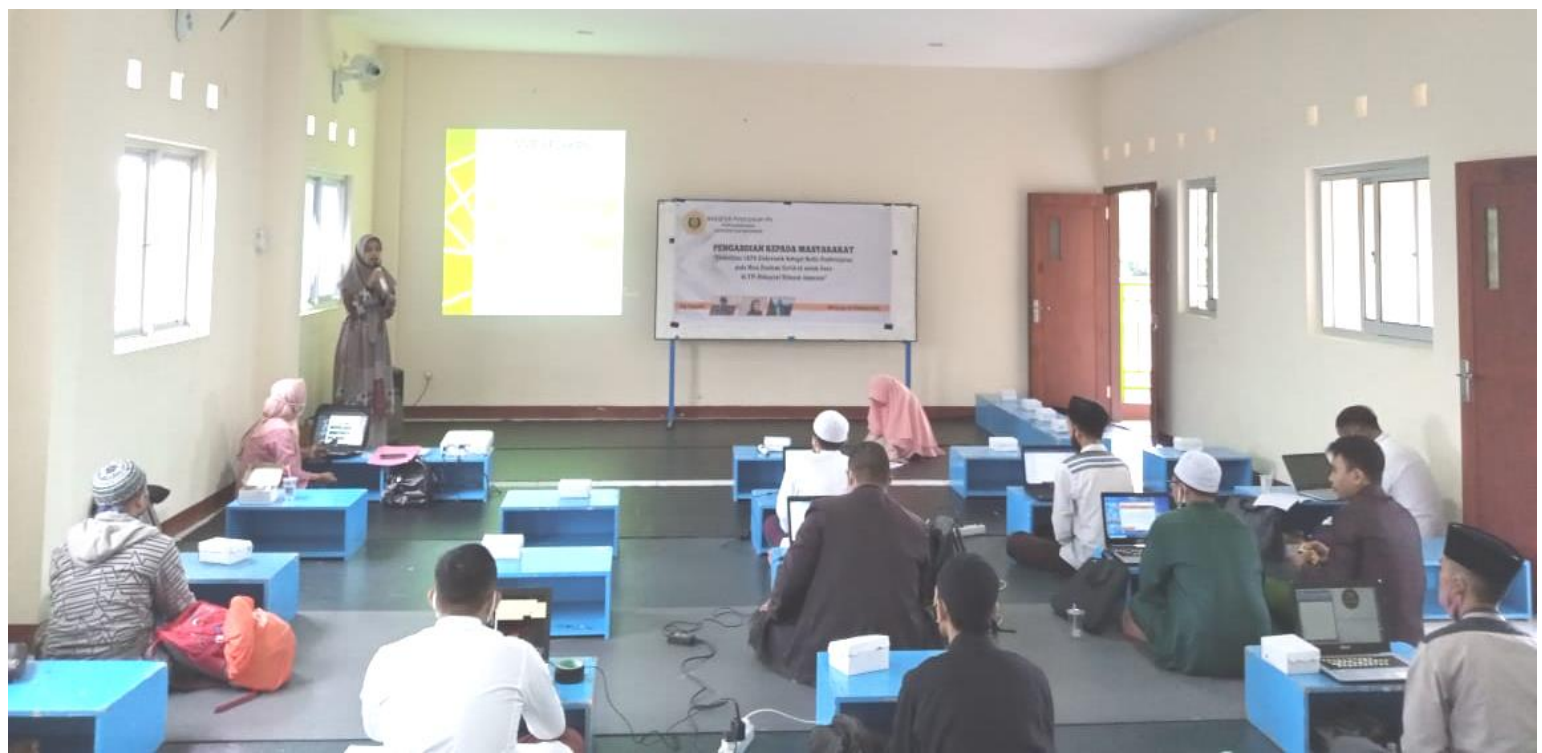

Gambar 3. Penyampaian Materi Efektivitas LKPD Elektronik sebagai Media Pembelajaran pada Masa Pandemic Covid-19.

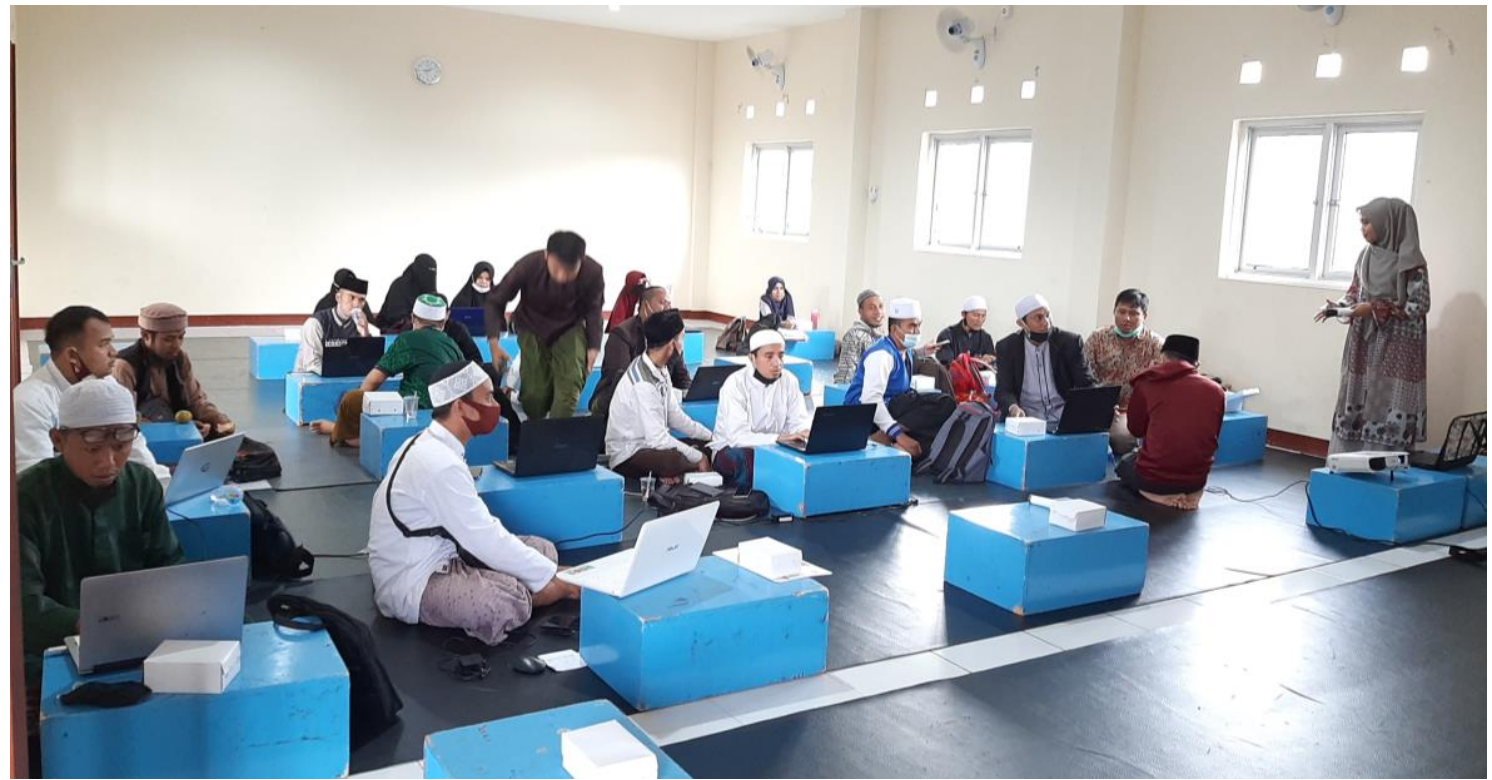

Gambar 4. Pelatihan Pembuatan LKPD Elektronik oleh Guru.

\section{Hasil dan Pembahasan}

Penyajian bahan ajar tidak hanya terbatas pada media cetak saja, akan tetapi sudah memanfaatkan media digital. Inovasi dalam mengembangkan suatu bahan ajar dalam kegiatan pembelajaran. Salah satunya bahan ajar yang dapat di transformasikan penyajiannya kedalam bentuk elektronik yaitu LKPD (Fahmi \& Rusmiamto, 2016). LKPD elektronik merupakan sebuah bentuk penyajian bahan ajar yang disusun secara sistematis kedalam unit pembelajaran tertentu yang disajikan dalam format elektronik yang didalamnya terdapat animasi, gambar, video, navigasi yang membuat pengguna lebih interaktif dengan program. Media elektronik yang dapat diakses oleh peserta didik mempunyai manfaat dan karakteristik yang berberda-beda. Jika ditinjau dari manfaatnya media elektronik sendiri dapat menjadikan proses pembelajaran lebih menarik (Puspitasari, 2019).

Pada kegiatan pengabdian ini, LKPD elektronik dibuat menggunakan aplikasi Liveworksheet yang dapat diakses pada halaman web https://www.liveworksheets.com/. Untuk dapat 
membuat LKPD elektronik dengan aplikasi tersebut, terlebih dahulu harus melakukan registrasi sehinngga para guru memiliki akses pada Liveworksheet. Setelah membuat akun, guru dapat mengupload LKPD yang sebelumnya telah dibuat dalam format file PDF menjadai LKPD elektronik yang nantinya bisa diakses oleh peserta didik melalui link LKPD yang dibagikan oleh guru. Pada saat mengupload LKPD yang dibuat kemudian diberi kode sesuai dengan jenis soal atau

LKPD elektronik yang dibuat melalui apliskasi ini memiliki beberapa keunggulan, yaitu mudah digunakan, praktis serta memiliki berbagai fitur yang dapat membuat LKPD menjadi lebih menarik. Pada LKPD guru dapat memuat materi, video pembelajaran, link, audio dan berbagai macam jenis soal seperti soal pilihan ganda, isian singkat, drop \& down, dan lainnya. Selain itu, jawaban LKPD yang telah dikerjakan oleh peserta didik akan dikirim ke akun dan email guru yang telah didaftarkan sebelumnya kemudian secara otomatis nilai dari peserta didik akan diproses oleh system. Hal ini memberikan keuntungan bagi guru, dimana guru tidak perlu mengkoreksi secara manual jawaban dari peserta didik.

Berdasarkan hasil wawancara yang dilakukan setelah kegiatan selesai dilaksanakan, didapatkan informasi bahwa guru-guru di YPI bidayatul hidayah sangat antusias terhadap pelaksanaan kegiatan karena mendapatkan pengetahuan baru terkait pengembangan LKPD elektronik. Peserta kegiatan pengabdian (guru) merasa bahwa LKPD elektronik ini sangat memberikan manfaat dan dapat membantu guru dalam menciptakan media pembelajaran alternative juga menyenangkan. Kedepannya diharapkan ada kegiatan lebih lanjut mengenai pembuatan LKPD elektronik ini sehingga guru-guru bisa secara maksimal membuat dan mengembangkan LKPD untuk proses pembelajaran baik secara daring maupun luring.

\section{Kesimpulan}

Berdasarkan hasil dan pembahasan sebelumnya, maka dapat disimpulkan bahwa LKPD elektronik merupakan salah satu media alternatif yang dapat digunakan oleh guru dalam melakukan kegiatan pembelajaran pada saat pandemic-Covid 19.

\section{Ucapan Terima Kasih}

Pengabdian ini terlaksana berkat kerjasama dan batuan dari berbagai pihak. Terutama Bapak Dr. Jamaluddin, M.Pd dan Bapak Dr. Drs. Abdul Syukur, M.Si., selaku dosen pengampu Mata Kuliah Studi Mandiri, YPI Bidayatul Hidayah Ampenan yang telah membantu kegiatan pengabdian sehingga terlaksana dengan baik, serta Program Studi Pascasarjana Universitas Mataram. Bersama ini kami tim pengabdian mengucapkan terima kasih atas segala bantuan dan kerjasamanya.

\section{Daftar Pustaka}

Arief, M. F. M. (2015). Pengembangan Lembar Kerja Siswa (LKS) pada Pembelajaran Mekanika Teknik dengan Pendekatan Kontekstual Untuk Siswa Kelas X TGB SMKN 2 Surabaya. Jurnal Pendidikan Teknik Bangunan. Vol. 1 (1): 148-152.

Departemen Pendidikan Nasional. (2004). Pedoman Umum Pengembangan Bahan Ajar Sekolah Menengah Atas. Departemen Pendidikan Nasional, Direktorat Pendidikan Menengah Umum.

Dewi, P. F. (2010). Pengembangan Lembar Kerja Siswa (LKS) Interaktif pada Pelajaran Kimia Pokok Bahasan Hidrokarbon di SMA Negeri 5 Palembang. Skripsi. Palembang: FKIP Universitas Sriwijaya.

Djamarah, S. B., \& Zain, A. (2002). Media Pembelajaran. Jakarta: Rineka Cipta.

Fahmi Dian Awaluddin, R. F., \& Rusimamto, P. W. (2016). Pengembangan Modul Elektronik Plc Pada Standar Kompetensi memprogram Peralatan Sistem Pengendali Elektronik Dengan Plc Untuk Smk Raden Patah Kota Mojokerto. Jurnal Pendidikan Teknik Elektro, 5(3).

Herawati, E. P., Gulo, F., \& Hartono, H. (2016). Pengembangan lembar kerja peserta didik (lkpd) interaktif untuk pembelajaran konsep mol di kelas X SMA. Jurnal Penelitian Pendidikan Kimia: Kajian Hasil Penelitian Pendidikan Kimia, 3(2), 168-178.

KEBUDAYAAN, M. P. D., \& INDONESIA, R. (2020). Surat Edaran Nomor 4 Tahun 2020 tentang Pelaksanaan Kebijakan Pendidikan dalam Masa Darurat Penyebaran Coronavirus Disease (COVID-19). 
Muhson, A. (2010). Pengembangan media pembelajaran berbasis teknologi informasi. Jurnal Pendidikan Akuntansi Indonesia, 8(2).

Prastowo, A. 2015. Panduan Kreatif Membuat Bahan Ajar Inovatif. Yogyakarta: DIVA Press.

Puspitasari, A. D. (2019). Penerapan Media Pembelajaran Fisika Menggunakan Modul Cetak dan Modul Elektronik pada Siswa SMA. Jurnal Pendidikan Fisika, 7(1), 17-25.

Putria, H., Maula, L. H. and Uswatun, D. A. (2020). Analisis Proses Pembelajaran dalam Jaringan (Daring) Masa Pandemi Covid-19 pada Guru Seklah Dasar. Jurnal Basicedu, Volume 4, Nomor 4, halaman 861-872.

Ramadhani, F. 2020. Penerapan Model Pembelajaran Project Based Learning (PJBL) Untuk Meningkatkan Hasil Belajar Ipa Pada Materi Bioteknologi Dan Produksi Pangan Dalam Pembelajaran Daring. Jurnal Pelita Pendidikan, 8(4).

Ramlawati, Liliasari, Martoprawiro, M. A., dan Wulan, A.R. (2014).The Effect of Electronic Portfolio Assessment Model to Increase of Student's Generic Science Skills in Practical Inorganic Chemistry. J. Educ. L., 8 (3):179186. 